\title{
TIG AISI-316 welds using an inert gas welding chamber and different filler metals: Changes in mechanical properties and microstructure ${ }^{(\bullet)}$
}

\author{
M. Pascual*, F. Salas*, F. J. Carcel**, M. Perales* y A. Sánchez*
}

\begin{abstract}
This report analyses the influence of the use of an inert gas welding chamber with a totally inert atmosphere on the microstructure and mechanical properties of austenitic AISI 316L stainless steel TIG welds, using AISI ER316L, AISI 308L and Inconel 625 as filler metals. When compared with the typical TIG process, the use of the inert gas chamber induced changes in the microstructure, mainly an increase in the presence of vermicular ferrite and ferrite stringers, what resulted in higher yield strengths and lower values of hardness. Its effect on other characteristics of the joins, such as tensile strength, depended on the filler metal. The best combination of mechanical characteristics was obtained when welding in the inert gas chamber using Inconel 625 as filler metal.
\end{abstract}

\section{Soldadura TIG del Acero AISI-316 en cámara inerte y con diferentes metales de aporte: Cambios en su microestructura y propiedades mecánicas}

\begin{abstract}
Resumen
En este estudio se analiza la influencia que el uso de una cámara de soldadura de gas inerte tiene sobre la microestructura y las propiedades mecánicas de las soldaduras TIG en el acero inoxidable austenítico AISI-316L cuando se emplean AISI ER316L, AISI 308L e Inconel 625 como materiales de aporte. Cuando se compara con el típico proceso de TIG, el uso de una cámara de gas inerte induce cambios en la microestructura, incrementando la presencia de ferrita vermicular y de laminillas de ferrita, resultando en un aumento del límite elástico y una pérdida de dureza. Su influencia sobre otras características de las soldaduras como la carga de rotura depende de la composición del material de aporte. La mejor combinación de propiedades mecánicas se obtuvo usando el Inconel 625 como material de aporte y soldando en la cámara de gas inerte.
\end{abstract}

Palabras clave

Soldadura; Cámara de gas inerte; Acero inoxidable.

\section{INTRODUCTION}

Stainless steels are a group of high-alloy steels based on $\mathrm{Fe}-\mathrm{Cr}$ and $\mathrm{Fe}-\mathrm{Cr}-\mathrm{Ni}$ systems with a minimum of $10.5 \mathrm{wt} \%$ chromium. This and the presence of other alloy elements as Mo, C, Ti, Nb, Si or Mn give them their excellent high-temperature and corrosion resistance. Unlike other materials, stainless steels are classified according to their metallurgical phases: austenitic, ferritic, duplex or martensitic.

Austenitic stainless steels represent the largest of the general groups of stainless steels and their main alloy elements are: $\mathrm{C}$ in a proportion of less than $0.1 \%$, Cr of between 16 and $25 \%$, Ni of between 8 and $20 \%$ (which is the gammagenous element that retains the austenitic face centred cubic structure at room temperature), Mo between 0 and $3 \%$ and $\mathrm{Mn}, \mathrm{Ti}$, $\mathrm{Nb}$ and $\mathrm{Cu}$ in lower proportion. These steels are easily welded but the problem arise when welding involves the formation of chrome carbides on grain boundaries and the loss of chrome content in the nearby grains if temperature is maintained between 500 and $800^{\circ} \mathrm{C}$, producing heat sensitization and cracking of the austenite. Low-carbon steels have a minimum carbon

\footnotetext{
(•) Trabajo recibido el día 27 de Enero de 2010 y aceptado en su forma final el día 2 de Mayo de 2010.

* Departamento de Ingeniería Mecánica y de Materiales. Universidad Politécnica de Valencia. Camino de Vera, s/n 46022 - Valencia. España.

${ }^{*}$ Departamento de Ingeniería de la Construcción, Universidad Politécnica de Valencia. Camino de Vera, s/n 46022 - Valencia. España.
} 
content in order to reduce carbide formation and avoid this problem. AISI-316L is one of these steels, which has a very good combination of mechanical properties and corrosion resistance.

Despite these characteristics, if proper precautions are not taken during welding, the changes in the microstructure can modify its behaviour ${ }^{[1-3]}$. Due to this fact, the optimization of this process continues attracting the interest of numerous researchers, who knows that the selection of the better combination of welding procedure and filler material is of paramount importance to obtain a weld with the desired characteristics. As examples, Lothengkum ${ }^{[4]}$ has studied the effect of TIG parameters on the delta-ferrite content in orbital welding of AISI-316L and Dafdar ${ }^{[5]}$ has evaluated the corrosion behaviour of stainless steel TIG welds in a physiological solution and has found that the heat affected zone (HAZ) was responsible for an increase in the corrosion rate. More recently, Naffakh has carried out an excellent work on the dissimilar welding of AISI-310 and Inconel $625^{[6]}$.

In this study the objective was to evaluate the influence of the use of an inert gas welding chamber on the microstructure, hardness and mechanical properties of AISI 316 TIG welds using three different filler metals.

\section{MATERIALS AND METHODS}

AISI-316L austenitic stainless steel samples consisting of metal sheets of size $200 \times 100 \times 1.5 \mathrm{~mm}$ were welded using three filler materials: AISI-316L, AISI-308L and
Inconel-625. Austenitic AISI 316L stainless steel has an fcc structure. It has good weldability due to its low carbon content, what makes it more difficult for chrome carbides to form on grain boundaries when welding. This steel is used extensively in the chemical and petrochemical industry.

Austenitic AISI-308L stainless steel is widely used, specially in manufacturing equipment for corrosive food products. It gives excellent results when applied as welding rods in welding. The formation of chrome carbides is minimal, as a consequence of the low level of carbon in its chemical composition.

Inconel is a registered trade name that includes nickel-chrome based alloys, covering a wide spectrum of compositions and properties ${ }^{[7]}$. Nickel and chrome act in conjunction to resist rusting, carburising and other forms of deterioration at high temperatures. In essence, the effect of nickel, which gives way to an increase in toughness and ductility, is combined with the effect of chrome, which consists in an improvement in its hardenability and wear resistance. This alloy contains $4 \%$ of niobium. Niobium has a higher affinity for carbon than chrome and thus forms carbides more easily than chrome, assuring a good resistance against intergranular corrosion.

All of these alloys do not become brittle at cryogenic temperatures ${ }^{[8]}$ and show good breakage resistance properties at high temperatures. Table I shows their chemical composition and mechanical characteristics. This data was provided by the supplier.

For each filler metal, two groups of welds were performed on the longest side, horizontally, one using the conventional TIG procedure in which the inert gas (Argon) is supplied through the ceramic nozzle on

Table I. Chemical composition and mechanical characteristics of welding rods

Tabla I. Composición química y características mecánicas de los materiales de aporte

\begin{tabular}{|c|c|c|c|c|c|c|c|c|c|c|c|}
\hline \multicolumn{12}{|c|}{ Chemical composition of filler metals } \\
\hline Steel & C & $\mathrm{Mn}$ & Si & $\mathrm{Cu}$ & $\mathrm{Cr}$ & $\mathrm{Ni}$ & Mo & $\mathrm{Nb}$ & $\mathrm{Fe}$ & $\mathbf{S}$ & Others \\
\hline AISI 308L & 0.03 & 1.0 & 0.65 & 0.75 & 19.5 & 10 & 0.75 & & & 0.03 & 0.5 \\
\hline AISI 316L & 0.03 & 1.0 & 0.65 & 0.75 & 18.0 & 14 & 2.50 & & & 0.03 & 0.5 \\
\hline INCONEL625 & 0.1 & 0.5 & 0.5 & & 20 & 58 & 9 & 4 & 5 & & rest \\
\hline \multicolumn{12}{|c|}{ Mechanical properties } \\
\hline Steel & \multicolumn{3}{|c|}{$\sigma_{Y}(\mathrm{MPa})$} & \multicolumn{3}{|c|}{$\sigma_{\mathrm{R}}(\mathrm{MPa})$} & \multicolumn{2}{|c|}{$\% \mathrm{~A}$} & \multicolumn{3}{|c|}{ HV } \\
\hline AISI 308L & \multicolumn{3}{|c|}{310} & \multicolumn{3}{|c|}{530} & \multicolumn{2}{|c|}{37} & \multicolumn{3}{|c|}{$<180$} \\
\hline AISI 316L & \multicolumn{3}{|c|}{310} & \multicolumn{3}{|c|}{540} & \multicolumn{2}{|c|}{25} & \multicolumn{3}{|c|}{$<180$} \\
\hline INCONEL625 & \multicolumn{3}{|c|}{515} & \multicolumn{3}{|c|}{850} & \multicolumn{2}{|c|}{50} & \multicolumn{3}{|c|}{200} \\
\hline
\end{tabular}


the gun, and other using an inert gas chamber, which can be seen in figure 1 . In this chamber, air was displaced by a continuous supply of $30 \mathrm{l} / \mathrm{min}$ of argon in order to obtain a total absence of active gases. The chamber has a sliding PMMA cover with a hole that is used to introduce the rod an internal supports for the steel samples.

The welding parameters used for the conventional TIG welds and the ones carried out at the inert gas chamber can be seen in table II.

The gross energy expenditure (GEE) and the net energy expenditure (NEE) for the different processes were determined by the expressions below:

$$
\begin{aligned}
& N E E=\rho \frac{U \cdot I \cdot 60}{v} \\
& G E E=\frac{U \cdot I \cdot 60}{v}
\end{aligned}
$$

Where U (voltage in Volts), I (intensity in Amperes), $\mathrm{v}$ (velocity in $\mathrm{cm} / \mathrm{min}$ ) and $\rho=0.65$ (TIG process). A $20 \%$ reduction in energy expenditure was obtained with the use of the inert gas chamber regardless of the filler metal due to a reduction in intensity. The welding velocity could also be improved by a $10 \%$.

Once the welds for both experiments were processed, standardised tensile test specimens were prepared by low speed cutting and machining (using a great amount of lubricant to avoid excessive heat generation) in order to determine their mechanical

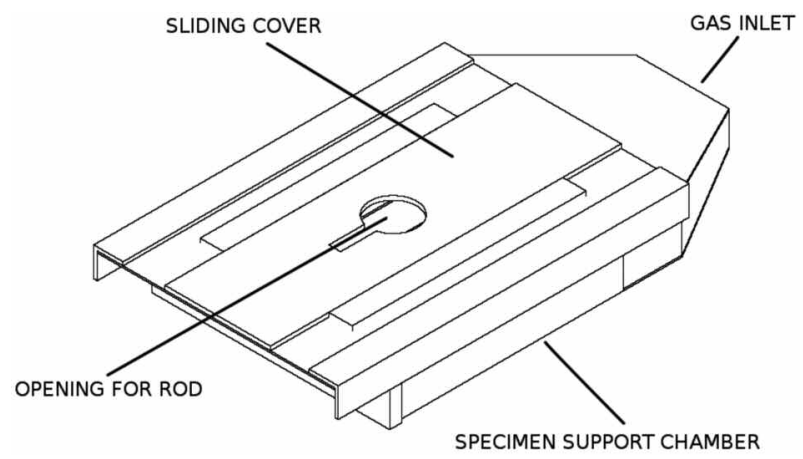

Figure1. Inert gas chamber. This chamber was made with stainless steel and the inert atmosphere is maintained by a continuous supply of argon.

Figura 1. Cámara de gas inerte. Esta cámara esta construida con acero inoxidable y la atmósfera inerte se mantiene mediante un aporte continuo de argón.

characteristics. A second group of test specimens was used to study their metallographic structure and hardness.

\section{RESULTS}

\subsection{Metallographic structure}

Figure 2 shows the microstructure $\mathrm{e}^{[9 \text { and } 10]}$ of the zone of transition from the bed to the base metal when

Table II. Welding parameters, read on the control panel of the welding equipment

Tabla II. Parámetros de soldeo, leídos en el panel del equipo de soldadura

316L Steel TIG Weld in ambient conditions

\begin{tabular}{lccccc}
\hline $\begin{array}{c}\text { ER source } \\
\text { material }\end{array}$ & $\begin{array}{c}\text { Voltage U } \\
\text { (Volts) }\end{array}$ & $\begin{array}{c}\text { Intensity I } \\
\text { (Amperes) }\end{array}$ & $\begin{array}{c}\text { Velocity v } \\
\text { cm/min }\end{array}$ & $\begin{array}{c}\text { GEE } \\
\text { (Joules/cm) }\end{array}$ & $\begin{array}{c}\text { NEE } \\
\text { (Joules/cm) }\end{array}$ \\
\hline AISI 316L & 20 & 45 & 11.42 & 4728.55 & 3073.55 \\
AISI 308L & 20 & 45 & 11.42 & 4728.55 & 3073.55 \\
INCONEL 625 & 20 & 45 & 10.90 & 4954.15 & 3220.20 \\
\hline \multicolumn{5}{l}{} \\
\hline \multicolumn{5}{l}{ AISI 316L Steel TIG Weld in inert gas chamber } \\
AISI 316L & 20 & 40 & 12.65 & 3794.50 & \\
AISI 308L & 20 & 40 & 12.65 & 3794.50 & 2466.45 \\
INCONEL 625 & 20 & 40 & 12.04 & 3986.71 & 2591.35 \\
\hline
\end{tabular}


using ER-316L as filler metal in room conditions (A) and when the inert gas chamber was used (B). An equiaxed austenitic structure typical of stainless steel can be observed on the left-hand side of each image. It is smaller than that of the base material, due to the changes that appear at the HAZ (heat-affected zone). At the near fusion boundary, the structure presents smaller equiaxial grains of austenite ( 1 in Fig. 2 ) with ferrite stringers ( 2 in Fig. 2). The morphology of the weld bed shows duplex structure of austenite plus skeletal ferrite (3 in Fig. 2), although near the base metal the ferrite becomes interdendritic (4 in Fig. 2).

The use of the gas chamber increased notably the size of the transition zone between the bed and the base metal. This is why figure $2 \mathrm{~b}$ ) presents a wider area of both interdendritic ferrite and ferrite stringers. Also, finely distributed chrome carbide precipitates were detected when the weld was performed in room conditions, but not when the inert gas chamber was used.

Figure 3 corresponds to the welds carried out with AISI 308L using the usual TIG procedure $(\mathrm{A})$ and the inert gas chamber (B). A completely austenitic structure can be observed in the base material for the HAZ, with a notable reduction in grain size for the samples that were welded using the gas chamber. At the bed, the use of the chamber induced a change from interdendritic (1 in Fig. 3) to skeletal ferrite ( 2 in Fig. 3), with zones of lathy ferrite ( 3 in Fig. 3), signal of a faster cooling due to the continuous argon supply.

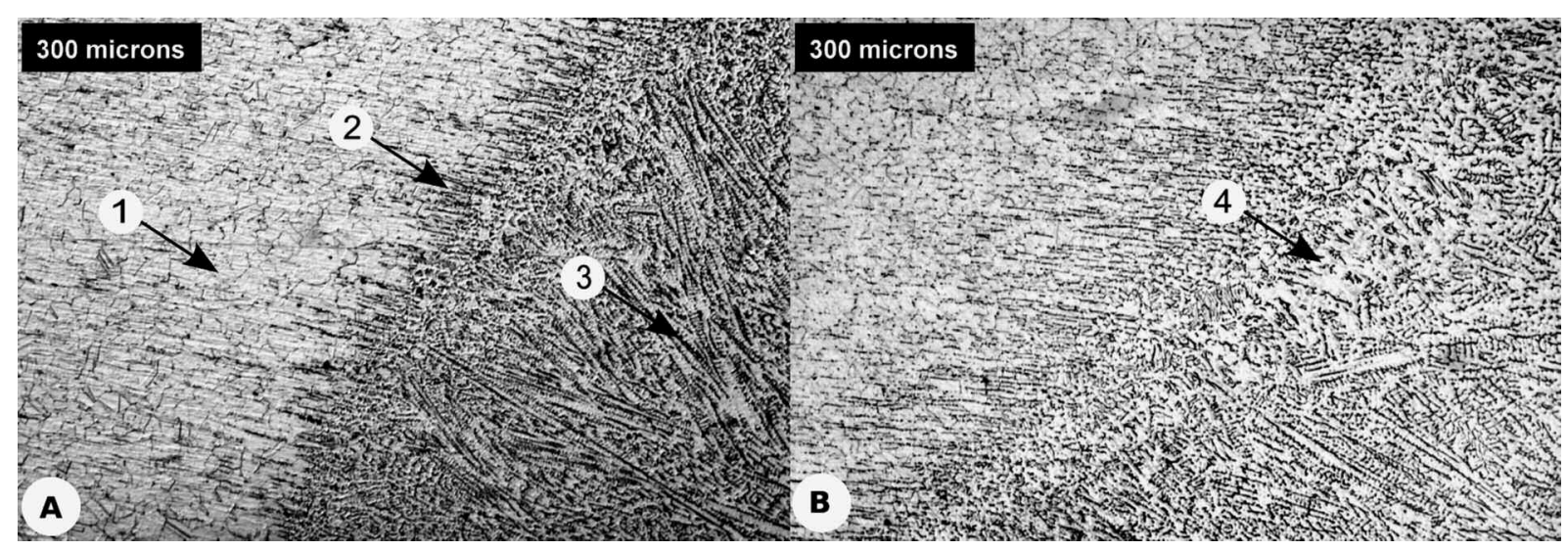

Figure 2. Micrographs of the AISI-316L steel (left side) welds with ER-316L as filler material (right side) in room conditions $(A)$ and using the inert gas chamber $(B)$.

Figura 2. Micrografías de las soldaduras de AISI-316L con ER-316L como material de aporte realizadas en condiciones ambientales $(A)$ y en la cámara de gas inerte $(B)$.

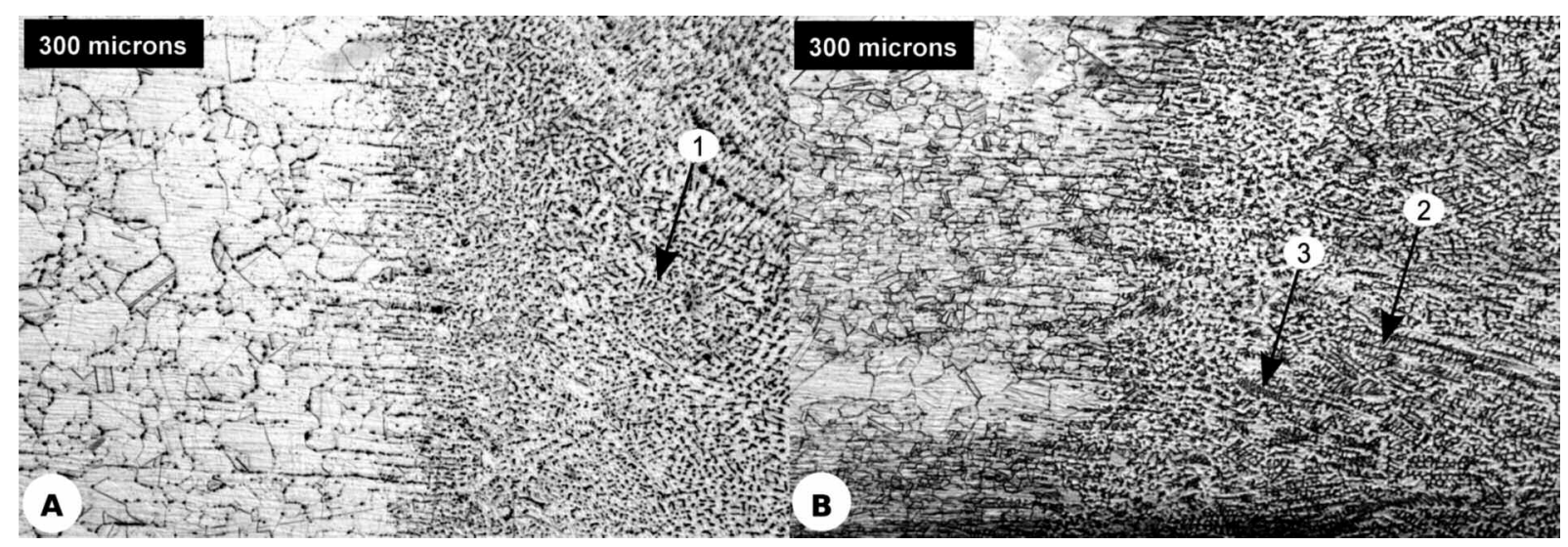

Figure 3. Micrographs of the AISI-316L steel welds with $308 \mathrm{~L}$ as filler material in ambient conditions $(A)$ and using the inert gas chamber $(B)$.

Figura 3. Micrografías de las soldaduras de AISI-316L con 308L como material de aporte realizadas en condiciones ambientales $(A)$ y en la cámara de gas inerte (B). 
TIG AISI-316 WELDS USING AN INERT GAS WELDING CHAMBER AND DIFFERENT FILLER METALS: CHANGES IN MECHANICAL PROPERTIES AND MICROSTRUCTURE SOLDADURA TIG DEL ACERO AISI-316 EN CÁMARA INERTE Y CON DIFERENTES METALES DE APORTE: CAMBIOS EN SU MICROESTRUCTURA Y PROPIEDADES MECÁNICAS

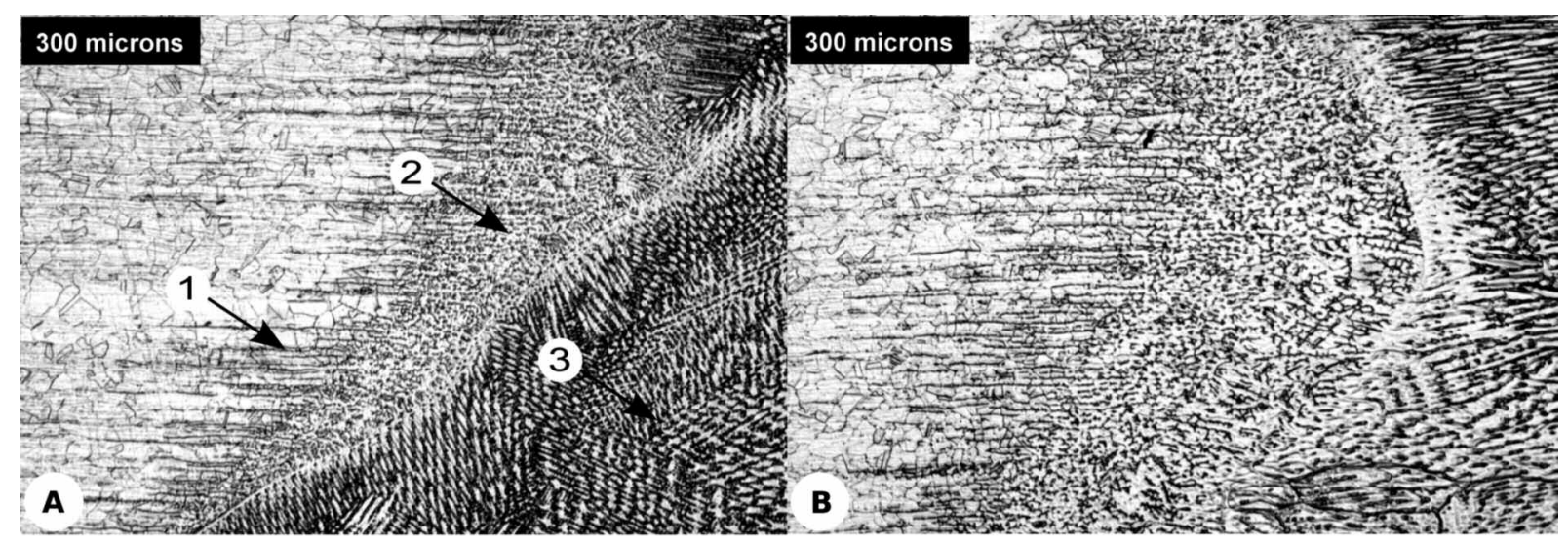

Figure 4. Micrographs of the AISI-316L steel welds with Inconel-625 as filler material in ambient conditions $(A)$ and using the inert gas chamber (B).

Figura 4. Micrografías de las soldaduras de AISI-316L con Inconel-625 como material de aporte realizadas en condiciones ambientales $(A)$ y en la cámara de gas inerte $(B)$.

The micrographs (Fig. 4) of the AISI 316L steel welded with INCONEL-625 shows the same structures than the other two: a reduction of austenitic grain size at the HAZ, ferrite stringers (1 in Fig. 4) at the near fusion boundary and a zone of interdendritic ferrite ( 2 in Fig. 4) at the beginning of the bed. This transition zone is wider than in the other cases due to the presence of niobium in the filler metal ${ }^{[6]}$. Because of the great differences in composition between INCONEL-625 and AISI-316L, the weld bed, which presents a fully austenitic columnar solidification ( 3 in Fig. 4), is separated from the partially melted zone by a clearly marked line.

\subsection{Mechanical characteristics}

Table III shows the tensile characteristics of the various joints according to the standardized tests

Table III. Mechanical characteristics of the different welds. When compared with the characteristics of AISI-316L, the use of the inert gas chamber and Inconel-625 shows a great similarity.

Tabla III. Características mecánicas de las distintas soldaduras. Cuando se comparan con las del AISI-316, la mayor similitud se encuentra usando Inconel-625 como material de aporte.

\begin{tabular}{lcccccc}
\hline \multicolumn{7}{c}{ 316L Steel TIG Weld in ambient conditions } \\
\hline $\begin{array}{c}\text { ER source } \\
\text { material }\end{array}$ & $\begin{array}{c}\text { Yield } \\
\text { strength } \\
\text { MPa }\end{array}$ & $\begin{array}{c}\text { Tensile } \\
\text { strength } \\
\text { MPa }\end{array}$ & $\begin{array}{c}\text { Bending } \\
\text { stress } \\
\text { MPa }\end{array}$ & \multicolumn{3}{c}{ Hardness (HV) } \\
\cline { 5 - 7 } & 347.5 & 501 & 19 & 321 & 339 & Interf. \\
AISI 316L & 331.5 & 496 & 19 & 255 & 259 & Base \\
material & Weld bed \\
INCI 308L & 320.0 & 420 & 17 & 227 & 222 & 214 \\
\hline & AISI 316L Steel TIG Weld in inert gas chamber & \\
\hline AISI 316L & 375.0 & 470 & 17.0 & 220 & 200 & 218 \\
AISI 308L & 373.0 & 413 & 17.8 & 203 & 207 & 183 \\
INCONEL 625 & 386.5 & 520 & 18.0 & 154 & 183 & 155 \\
\hline
\end{tabular}


specified in UNE-EN 895 and hardness in the bed, interface and heat affected zone (HAZ), as per Standard UNE 6507-01.

As can be seen in tables 1 and 3 , the microstructural changes that appear due to the presence of a weld bed -when the inert gas chamber is not used-increase the elastic limit of the material but reduce its tensile strength and its strain. At the same time, hardness at the weld increases notably if compared to the original alloy if the filler metals are the stainless steels but experiment no substantial changes if Inconel 625 is used. These facts imply a slight deterioration of the mechanical characteristics of the welded structure due to fact that the weld is a linear zone of higher fragility.

The use of an inert gas chamber and stainless steel rods increases even more the yield strength despite the filler metal and reduces the tensile strength. On the other side, a much less increment in hardness is noted when welding in the inert gas chamber, in fact the reduction in hardness ranges from a $28 \%$ with $308 \mathrm{~L}$ as filler metal to more than $50 \%$ with $316 \mathrm{~L}$ as filler metal. Although the decrease in tensile strength is not desirable, the lower hardness values obtained with the use of the inert gas chamber lead to assuring a nonfragile behaviour of the joint, what can be useful.

This changes when Inconel-625 is the filler material. In this case, the yield strength reach its higher value, but the tensile strength, elongation and hardness are also improved, obtaining values, for some parameters, almost identical to that of the base metal: values of harness around $154 \mathrm{HV}$ were measured at the weld bed and the interface and a tensile strength only a $0.04 \%$ lesser than the corresponding to the base metal.

The different results corroborate the ones presented in other papers ${ }^{[11}$ and ${ }^{12]}$ on the use of Inconel as filler material and the good characteristics of the welds obtained with it, with only the inconvenient of a slight lower welding velocity, and the benefits of welding in an inert gas chamber, although, due to limitations in size and economic requirements, its use is only advisable for demanding applications, hard-to-weld metals and small elements.

\section{CONCLUSIONS}

- The use of an inert gas chamber resulted in a wider interface between the weld bed and the base metal, increasing both the presence of ferrite stringers and vermicular ferrite.

- Its use caused, in every case, a decrease of hardness and an increase of elongation and yield strength.
On the other hand, the tensile strength was reduced, except when Inconel 625 was used as filler metal.

- The weld carried out with Inconel 625 in the inert gas chamber, presented the best characteristics. It combined high elongation and the best mechanical properties of all, very similar to that of the original $316 \mathrm{~L}$, which assures the best behaviour of the joint by maintaining the continuity of the mechanical characteristics in a welded structure.

- In terms of welding velocity, the weld with the best characteristics was done with AISI 316L stainless steel and a welding rod made of the same material, performed in an inert chamber, which produced a corresponding decrease in Gross and Net Energy.

\section{REFERENCES}

[1] D.J. Lee, J.C. Byun, J.H. Sungy and H.W. Lee, Mater. Sci. Technol. A. 513-514 (2009) 154 159.

[2] D.J. Lee and K.H. Jung. Mater. Design. 30 (2006) 3.269-3.273.

[3] T.P.S. Gill, V. Shankar, M.G. Pujar and P. Rodriguez, Scripta Metall. Mater., 32 (1995) 1.595-1.600.

[4] G. Lothongkum, E. Viyanit and P. Bhandhubanyong. J. Mater. Process Tech. 110 (2001) 233-238.

[5] M. Gao, X. Zeng and Q. Hu, J. Mater. Process Tech. 184 (2007) 177-183.

[6] H. Naffakh, M. Shamanian and F. Ashrafizadeh, J. Mater. Process Tech. 209 (2008), pp. 3.6283.639.

[7] http://www.americanspecialmetals.com/inconel.html

[8] A. Nishimura, R.L. Tobler, H. Tamura, S. Imagawa and J. Yamamoto. Fusion Eng. Des. 42 (1998) 425-430.

[9] S. Kou, Welding metallurgy, Ed. John Wiley and Sons, $2^{\mathrm{a}}$ ed. New Jersey. 2003.

[10] J.C. Lippold and D.J. Kotecki. Welding metallurgy and soldability of stainless steel. Ed. John Wiley and Sons, New Jersey. 2005.

[11] J. Lee, C. Jang, J.S. Kim and T.E. Jin. Transactions, SMiRT 19, 2007, Paper G04/4.

[12] H. Naffakh, E.M. Shamanian and F. Ashrafizadeh, J. Mater. Sci. 43 (2008) 5.3005.304 . 